\title{
Pengaruh good governance dan standar akuntansi pemerintahan terhadap akuntabilitas keuangan dengan komitmen organisasi sebagai pemoderasi
}

\author{
Elvira Zeyn \\ Universitas Pasundan Bandung, Jawa Barat \\ Jl. Tamansari No. 6-8, Bandung \\ Email:z.hera@yahoo.co.id
}

\begin{abstract}
The purpose of this study are to analyze; the influence of implementation good governance, implementation accounting standards of government and the influence of financial accountability with organization commitment as moderating variables. The research samples are selected by using purposive method. The research method used were desciptive and verificative, and analysis method used the multiple regression, multiple correlation and determination method. The results of study show that implementation good governance with organization commitment have significant influence financial accountability; implementation accounting standards of government with organization commitment have significant influence financial accountability; implementation good governance and accounting standards of government with organization commitment have significant influence financial accountability.
\end{abstract}

Keywords: Good Governance, Standar accounting standards of government, Financial Accountability, Transparency, Organization Commitment.

\section{Pendahuluan}

Mengukur keberhasilan kebijakan, idealnya diletakkan pada kerangka kontinum waktu panjang, tidak hanya sesaat. Kendatipun reformasi memaksa terjadinya perubahan struktur (restrukturisasi) dengan penyesuaian daerah otonom, dimana disadari pemerintahan tidak lagi bercorak korporatis dan sentralistik pada kepemimpinan top executive di tangan bupati/wali kota. Politisasi birokrasi yang masih cukup kental mewarnai dinamika otonomi daerah. Hal ini, erat kaitannya juga dengan kegagalan hubungan kelembagaan eksekutif dan legislatif, karena proses menguatnya political society.

The fact that countries with poorly developed institutions receive more aid (if they do) may mean that donors are trying to help build institutions, not that aid is bad for good governance (Alberto Alesina and Beatrice Weder, 2002). Huther, Jeff and Anwar Shah (1998), in contrast, awareness campaigns would be expected to have a positive impact in countries where governance is fair or good and the incidence of corruption is low. Sunarsip (2001) mengemukakan bahwa terjadinya krisis ekonomi di Indonesia disebabkan oleh tata kelola yang buruk (bad governance) pada sebagian besar pelaku ekonomi (publik dan swasta). Salah satu usaha memulihkan kondisi ekonomi, sosial dan politik adalah dengan mengembalikan kepercayaan rakyat kepada pemerintah dengan mencoba mewujudkan suatu pemerintahan yang bersih dan berwibawa atau yang dikenal dengan istilah good governance. Oleh karena itu tuntutan terhadap terwujudnya good governance (tata kelola yang baik) sangat diperlukan terutama di instansi pemerintah. Upaya ini juga didukung oleh banyak pihak baik pemerintah sendiri sebagai lembaga ekse-

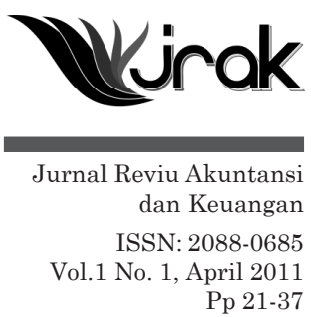




\section{Pengaruh good governance}

kutif, DPR sebagai lembaga legislatif, pers dan juga oleh lembaga-lembaga swadaya masyarakat.

Penetapan UU No. 22 tahun 1999 dan Undang-Undang No. 25 tahun 1999 oleh pemerintah, mengenai Pemerintah Daerah dan Perimbangan Keuangan Antara Pemerintah Pusat dan Daerah, berimplikasi pada tuntutan otonomi yang lebih luas dan akuntabilitas publik yang nyata yang harus diberikan kepada pemerintah daerah (Halim, 2001). Selanjutnya, Undang-Undang ini diganti dan disempurnakan dengan Undang-Undang No. 32 tahun 2004 dan Undang-Undang No. 33 tahun 2004. Kedua undang-undang tersebut telah merubah akuntabilitas atau pertanggungjawaban pemerintah daerah dari pertanggungjawaban vertikal (kepada pemerintah pusat) ke pertanggungjawaban horisontal (kepada masyarakat melalui DPRD).

Pada intinya semua peraturan tersebut menginginkan adanya transparansi dan akuntabilitas dalam pengelolaan keuangan daerah. Namun, setelah empat tahun berlakunya paket undang-undang tersebut, delapan tahun sejak otonomi yang luas kepada daerah, dan sepuluh tahun setelah reformasi, hampir belum ada kemajuan signifikan dalam peningkatan transparansi dan akuntabilitas keuangan Negara/Daerah. Laporan Keuangan Pemerintah Daerah (LKPD) dalam tiga tahun terakhir secara umum masih buruk (Siaran Pers, BPK RI, 23 Juni 2008). Kondisi ini semakin memburuk, sebagaimana di ungkapkan dalam siaran pers BPK RI pada tanggal 15 Oktober 2008 yaitu: dilihat dari persentase LKPD yang mendapatkan opini Wajar Tanpa Pengecualian (WTP) dan Wajar Dengan Pengecualian (WDP) selama periode 2004-2007 semakin menurun setiap tahunnya. Persentase LKPD yang mendapatkan opini WTP semakin berkurang dari 7\% pada tahun 2004 menjadi 5\% pada tahun berikutnya dan hanya 1\% pada tahun 2006 dan 2007. Sebaliknya, LKPD dengan opini Tidak Memberikan Pendapat (TMP) semakin meningkat dari $2 \%$ pada tahun 2004 menjadi $17 \%$ pada tahun 2007 dan pada periode yang sama opini Tidak Wajar (TW) naik dari 3\% menjadi $19 \%$. Selanjutnya hasil pemeriksaan BPK menunjukkan bahwa pengelolaan keuangan negara/daerah yang dilakukan pemerintah dalam Tahun 2008 masih menunjukkan banyak kelemahan dan baru menunjukkan tanda-tanda perbaikan, BPK memberikan opini WTP atas delapan Laporan keuangan pemerintah daerah (LKPD), opini WDP atas 217 LKPD, opini tidak wajar (TW) atas 21 LKPD, dan opini TMP atas 47 LKPD dari 293 LKPD Tahun 2008 yang telah diperiksa BPK pada Semester I Tahun 2009 (BPK, 2009).

Pembuatan laporan keuangan adalah suatu bentuk kebutuhan transparansi yang merupakan syarat pendukung adanya akuntabilitas yang berupa keterbukaan (openness) pemerintah atas aktivitas pengelolaan sumber daya publik. Transparansi informasi terutama informasi keuangan dan fiskal harus dilakukan dalam bentuk yang relevan dan mudah dipahami (Schiavo-Campo and Tomasi, 1999). Transparansi dapat dilakukan apabila ada kejelasan tugas dan kewenangan, ketersediaan informasi kepada publik, proses penganggaran yang terbuka,dan jaminan integritas dari pihak independen mengenai prakiraan fiskal, informasi, dan penjabarannya (IMF, 1998 dalam Schiavo-Campo and Tomasi, 1999).

Peraturan Pemerintah no. 105 tahun 2000 yang merupakan turunan dari UU no. 22 tahun 1999 kemudian menyebutkan secara tegas bahwa laporan pertanggungjawaban keuangan harus disajikan sesuai dengan standar akuntansi. Standar Akuntansi Pemerintahan (SAP) telah dimanatkan dalam berbagai peraturan perundang-undangan seperti UU no. 17 tahun 2003, UU no. 1 tahun 2004 dan UU no. 32 tahun 2004. Standar Akuntansi Pemerintahan (SAP) merupakan standar yang harus diikuti dalam laporan keuangan instansi pemerintah pusat dan pemerintah daerah. Pengguna laporan keuangan akan menggunakan SAP untuk memahami informasi yang disajikan dalam laporan keuangan dan menjadi pedoman untuk menyatukan persepsi antara penyusun, pengguna dan auditor (BPK). SAP ditetapkan dengan PP no. 71 tahun 2010. Laporan keuangan merupakan wujud pertanggungjawaban keuangan daerah dan merupakan tanggungjawab atas akuntabilitas publik serta merupakan salah satu ukuran keberhasilan (kinerja) pemerintah daerah (Jamanson Sinaga, 2005). 
Pengelolaan pemerintah daerah yang berakuntabilitas, tidak bisa lepas dari anggaran pemerintah daerah. Anggaran diperlukan dalam pengelolaan sumber daya tersebut dengan baik untuk mencapai kinerja yang diharapkan oleh masyarakat dan untuk menciptakan akuntabilitas terhadap masyarakat. Riyanto (2003) yang mengatakan perlunya penelitian mengenai pendekatan kontijensi berkaitan dengan kejelasan sasaran anggaran dan dampaknya agar hasil yang diperoleh akan lebih konsisten. Model penelitian tersebut untuk menguji contextual factors yang mempengaruhi hubungan antara sistem pengendalian dengan kinerja. Sistem pengendalian termasuk anggaran dan pendekatan kontijensi memungkinkan adanya variabel-variabel lain yang bertindak sebagai variabel intervening atau variabel moderating (Darma, 2004).

Penelitian-penelitian yang menggunakan variabel-variabel moderating untuk penelitian mengenai sistem pengendalian dan implikasinya dilakukan oleh Brownell dan McInnes, (1986) ; Mia, (1988) dalam Darma, (2004); Fahrianta dan Ghozali, (2002); Lucyanda, (2001) yang menggunakan motivasi sebagai variabel moderasi. Komitmen organisasi (Nouri dan Parker, 1996; Asnawi, 1997; Darlis, 2000, Chong dan Chong, 2002; Wentzel, 2002; Dwianasari, 2004), dan kultur organisasi (Connor, 1995). Komitmen organisasi merupakan variabel yang memegang peranan penting dalam hubungan antara kejelasan sasaran anggaran dan dampaknya. Komitmen organisasi merupakan keyakinan dan dukungan yang kuat terhadap nilai dan sasaran (goal) yang ingin dicapai organisasi (Mowday et al., 1979 dalam Darma, 2004).

Berdasarkan hasil penelitian, komitmen organisasi yang tinggi berpengaruh signifikan terhadap kinerja (Keller, 1997 dalam Darma, 2004). Selain itu, komitmen organisasi dapat merupakan alat bantu psikologis dalam menjalankan organisasinya untuk pencapaian sasaran yang diharapkan (Nouri dan Parker, 1996; McClurg, 1999; Chong dan Chong, 2002; Wentzel, 2002; Darma, 2004). Selanjutnya hasil penelitian Herlin (2010) menunjukkan tidak terdapat pengaruh antara komitmen organisasi terhadap kinerja organisasi melalui akuntabilitas publik. Sedangkan dari penelitian lainnya menunjukan terdapat pengaruh signifikan antara variabel komitmen organisasi dalam memoderasi partisipasi penyusunan anggaran dengan kinerja aparat pemrintah daerah (Bambang, 2006). Komitmen organisasi memiliki pengaruh positif terhadap akuntabilitas publik pada tingkat yang cukup (sedang). Kondisi ini memperlihatkan bahwa semakin baik komitmen organisasi akan mendorong keberhasilan akuntabilitas publik.

Akuntabilitas melalui anggaran meliputi penyusunan anggaran sampai dengan pelaporan anggaran. Laporan keuangan merupakan komponen penting untuk menciptakan akuntabilitas sektor publik dan merupakan salah satu alat ukur kinerja finansial pemerintah daerah (Indrawati Yuhertiana, 2007). Akuntabilitas keuangan mengharuskan pemerintah daerah menyusun laporan keuangan atas pelaksanaan keuangan daerah.

\section{Pengembang Hipotesis \\ Penerapan Good Governance}

Bersatu bertekad untuk mewujudkan kepemerintahan yang baik/amanah (good governance) yang merupakan prasyarat bagi setiap pemerintahan untuk memenuhi aspirasi masyarakat dan mencapai tujuan serta cita-cita bangsa dan negara. Sehubungan dengan hal tersebut, telah dilakukan berbagai upaya yaitu dengan ditetapkannya Tap.MPR RI No.XI/MPR/1998 tentang Penyelenggara Negara yang Bersih dan Bebas Korupsi, Kolusi, dan Nepotisme; Undangundang No.28 tahun 1999 tentang Penyelenggaraan Negara yang Bersih dan Bebas dari Korupsi, Kolusi, dan Nepotisme.

Good governance dapat diartikan sebagai pelayanan publik yang efisien, sistem pengadilan yang dapat diandalkan, pemerintahan yang bertanggung jawab (accountable) pada publiknya. Good governance adalah, penyelenggaraan pemerintahan yang solid dan bertanggungjawab serta efisien dan efektif dengan menjaga 


\section{Pengaruh good governance}

kesinergiaan interaksi yang konstruktif diantara domain- domain (state, private sector and society).

Tiga pilar elemen dasar yang saling berkaitan satu dengan lainnya dalam mewujudkan good governace (Osborne and Geabler, 1992, OECD and World Bank, 2000, LAN dan BPKP, 2000; 6) adalah sebagai berikut:

- Transparansi, yaitu keterbukaan dalam manajemen pemerintah, lingkungan, ekonomi dan sosial.

- Partisipasi, yaitu penerapan pengambilan keputusan yang demokratis serta pengakuan atas HAM, kebebasan pers dan kebebasan mengemukakan pendapat/ aspirasi masyarakat.

- Akuntabilitas, yaitu kewajiban melaporkan dan menjawab dari yang dititipi amanah untuk mempertanggungjawabkan kesuksesan maupun kegagalan kepada penitip amanah sampai yang memberi amanah puas dan bila belum ada atau tidak puas dapat kena sanksi.

\section{Standar Akuntansi Pemerintahan}

Standar Akuntansi Pemerintahan mengatur penyajian laporan keuangan untuk tujuan umum (general purpose financial statements) dalam rangka meningkatkan keterbandingan laporan keuangan baik terhadap anggaran, antar periode, maupun antar entitas. Laporan keuangan untuk tujuan umum adalah laporan keuangan yang ditujukan untuk memenuhi kebutuhan bersama sebagian besar pengguna laporan. Untuk mencapai tujuan tersebut, standar ini menetapkan seluruh pertimbangan dalam rangka penyajian laporan keuangan, pedoman struktur laporan keuangan, dan persyaratan minimum isi laporan keuangan.

Dalam PP no 71 tahun 2010 menyatakan bahwa, SAP Berbasis Akrual adalah SAP yang mengakui pendapatan, beban, aset, utang, dan ekuitas dalam pelaporan finansial berbasis akrual, serta mengakui pendapatan, belanja, dan pembiayaan dalam pelaporan pelaksanaan anggaran berdasarkan basis yang ditetapkan dalam APBN/APBD. SAP Berbasis Kas Menuju Akrual adalah SAP yang mengakui pendapatan, belanja, dan pembiayaan berbasis kas, serta mengakui aset, utang, dan ekuitas dana berbasis akrual. Laporan keuangan pokok terdiri dari: (a) Laporan Realisasi Anggaran; (b) Neraca; (c) Laporan Arus Kas; (d) Catatan atas Laporan Keuangan. Selain laporan keuangan pokok tersebut, entitas pelaporan diperkenankan menyajikan Laporan Kinerja Keuangan dan Laporan Perubahan Ekuitas (PSAP, KK; 2010).

The flexibility and the focus on performance are linked to an increase in accountability for financial and operating results and the annual report is a very important tool in this respect. "Government accounting shall be performed according to generally accepted accounting practice, and further regulations on accounting shall be issued by the government or an agency designated by the government. Reports shall give a true and fair view of operations, financial performance and position, and the stewardship of financial and other assets", (Kristina Lundqvist, 2001). Setiap entitas pelaporan mempunyai kewajiban untuk melaporkan upaya-upaya yang telah dilakukan serta hasil yang dicapai dalam pelaksanaan kegiatan secara sistematis dan terstruktur pada suatu periode pelaporan untuk kepentingan akuntabilitas, manajemen, transparansi, keseimbangan antargenerasi dan evaluasi kinerja (PSAP KK,2010).

\section{Komitmen Organisasi}

Komitmen terhadap organisasi merupakan suatu dimensi perilaku yang dapat digunakan untuk mengevaluasi kekuatan para karyawan untuk bertahan pada suatu perusahaan. Membuat karyawan agar memiliki komitmen yang tinggi adalah sangat penting, terutama pada perusahaan-perusahaan non-profit yang 
skala gajinya tidak kompetitif, seperti pada perusahaan industri (Munandar, 2001:453). Karyawan yang memiliki tingkat komitmen organisasi yang tinggi tidak sekedar bergabung dengan perusahaan secara fisik atau hanya mengerjakan sesuatu yang menjadi tugasnya, melainkan juga bersedia melakukan pekerjaan diluar tugasnya (SWA, 2000, Agustus).

Penelitian terkait dengan komitmen organisasi dilakukan oleh Natalie J Allen dan John P Meyer (1990), tentang pengukuran anteseden dari komitmen organisasi. Berdasarkan hasil penelitian ditemukan bahwa komponen affective dan continuance pada komitmen organisasi secara empiris merupakan konstruk yang dapat dipisahkan dengan tidak ada korelasi. Komponen afektif dan normatif dapat dibedakan, namun terkait keduanya. Komitmen organisasi dibangun melalui identifikasi individual dengan tujuan organisasi (affective commitment) dan biaya terkait dengan tetap tinggalnya seseorang pada suatu organisasi (the "side-bet" theory atau continuance commitment) serta apa yang sebaiknya dilakukan (normatif commitment) (Meyer, 1990;1).

Buchanan dalam Vandenberg (1992) mendefinisikan komitmen adalah sebagai penerimaan karyawan atas nilai-nilai organisasi (identification), keterlibatan secara psikologis (psychological immerson), dan loyalitas (affection attachement). Komitmen merupakan sebuah sikap dan perilaku yang saling mendorong (reinforce) antara satu dengan yang lain. Selanjutnya Allen \& Meyer (dalam Dunham, dkk 1994) membedakan komitmen organisasi atas tiga komponen, yaitu:

- Komitmen afektif (Afective Commitment), melibatkan rasa memiliki dan terlibat didalam organisasi.

- Komitmen kontinuans (Continuance Commitment), dimensi komitmen ini atas dasar besar kecilnya pembiayaan yang akan ditanggung oleh karyawan jika meninggalkan organisasi. Tentu saja dalam hal ini erat kaitannya dengan kemampuan seseorang untuk memperhitungkan resiko yang akan diambilnya. Jadi yang menentukan komitmen adalah faktor rasional.

- Komitmen normatif (Normative Commitment), komitmen ini lebih menekankan kepada keterlibatan perasaan dan menggambarkan dedikasi seseorang untuk tetap tinggal dan bekerja pada organisasinya.

Komitmen organisasional menunjukkan suatu daya dari seseorang dalam mengidentifikasikan keterlibatannya dalam suatu bagian organisasi (Mowday, et al. dalam Vandenberg, 1992). Komitmen organisasional dibangun atas dasar kepercayaan pekerja atas nilai-nilai organisasi, kerelaan pekerja membantu mewujudkan tujuan organisasi dan loyalitas untuk tetap menjadi anggota organisasi. Oleh karena itu, komitmen organisasi akan menimbulkan rasa ikut memiliki (sense of belonging) bagi pekerja terhadap organisasi. Jika pekerja merasa jiwanya terikat dengan nilai-nilai organisasional yang ada maka dia akan merasa senang dalam bekerja, sehingga mempunyai tanggungjawab dan kesadaran dalam menjalankan organisasi dan termotivasi melaporkan semua aktivitas dengan melaksanakan akuntabilitas kepada publik secara sukarela termasuk akuntabilitas keuangannya dan kinerjanya dapat meningkat

\section{Akuntabilitas Keuangan}

Akuntabilitas merupakan salah satu unsur pokok perwujudan good governance yang saat ini sedang diupayakan di Indonesia. Pemerintah diminta untuk melaporkan hasil dari program yang telah dilaksanakan sehingga masyarakat dapat menilai apakah pemerintah telah bekerja dengan ekonomis, efisien dan efektif. Akuntabilitas dapat dilihat dari perspektif akuntansi, perspektif fungsional dan perspektif sistem akuntabilitas (Sadjiarto, 2000). 


\section{Pengaruh good governance}

Dalam penyelenggaraan pemerintahan, akuntabilitas pemerintah tidak dapat diketahui tanpa pemerintah memberitahukan kepada rakyat tentang informasi sehubungan dengan pengumpulan sumber daya dan sumber dana masyarakat beserta penggunaannya. Hopwood dan Tomkins (1984) dan Edwood (1993), Mahmudi, (2005;10), dan Syahrudin Rasul (2003), mengemukakan salah satu akuntabilitas publik adalah akuntabilitas financial (keuangan) dimana mengharuskan lembaga-lembaga publik untuk membuat laporan keuangan untuk menggambarkan kinerja financial organisasi kepada pihak luar.

Pemerintah daerah melaksanakan amanah dari masyarakat dalam bentuk pengelolaan keuangan daerah dituntut untuk dapat transparan dan akuntabel dalam pentanggungjawabannya. Transparansi informasi terutama informasi keuangan dan fiskal harus dilakukan dalam bentuk yang relevan dan mudah dipahami (Schiavo-Campo and Tamosi, 1999). Salah satu akuntabilitas yang penting berkaitan dengan pengelolaan keuangan daerah adalah akuntabilitas keuangan.

Akuntabilitas keuangan merupakan pertanggungjawaban lembaga-lembaga publik untuk menggunakan dana publik (public money) secara ekonomis, efisien dan efektif, tidak ada pemborosan dan kebocoran dana, serta korupsi. Akuntabilitas keuangan ini sangat penting karena menjadi sorotan utama masyarakat. Akuntabilitas ini mengharuskan lembaga-lembaga publik untuk membuat laporan keuangan untuk menggambarkan kinerja finansial organisasi kepada pihak luar. Akuntabilitas keuangan terkait dengan penghindaran penyalahgunaan dana publik (Mardiasmo, 2002;21). Tahap-tahap dalam Akuntabilitas keuangan, mulai dari perumusan rencana keuangan (proses penganggaran), pelaksanaan dan pembiayaan kegiatan, evaluasi atas kinerja keuangan, dan pelaksanaan pelaporannya (LAN, 2001 dalam Malik Imron, 2005). Dengan kata lain akuntabilitas terkandung kewajiban menyajikan dan melaporkan pengelolaan keuangan daerah kedalam laporan keuangan daerah. Laporan keuangan salah satu alat untuk menfasilitasi terciptanya transparansi dan akuntabilitas publik. Laporan keuangan pemerintah daerah disajikan secara komprehensif (Mardiasmo, 2002;36).

Good governance menghendaki pemerintahan dijalankan dengan mengikuti prinsip-prinsip pengelolaan yang baik, seperti transparansi (keterbukaan), akuntabilitas, partisipasi, keadilan, dan kemandirian, sehingga sumber daya negara yang berada dalam pengelolaan pemerintah benar-benar mencapai tujuan sebesarbesarnya untuk kemakmuran dan kemajuan rakyat dan negara. Penerapan prinsipprinsip good governance dalam penyelenggaraan negara tak lepas dari masalah akuntabilitas dan tranparansi dalam pengelolaan keuangan negara dan daerah (Cadbury,1992 yang dikutip Media Akuntansi 2000 dalam Sunarto,2003).

Sebagian besar penelitian tentang good governance di tingkat perusahaan dilakukan di Amerika dan negara-negara anggota Organization for Economic $\mathrm{Co}^{-}$ operation and Development (OECD) (Shleifer dan Vishny, 1997). Penelitian dilakukan di negara yang sedang berkembang masih sangat sedikit. Black (2001) berargumen bahwa pengaruh praktek good governance terhadap nilai perusahaan akan lebih kuat di negara berkembang dibandingkan di negara maju. Hal tersebut dikarenakan oleh lebih bervariasinya praktik good governance di negara berkembang dibandingkan negara maju. Durnev dan Kim (2002) memberikan bukti bahwa praktik good governance lebih bervariasi di negara yang memiliki hukum lebih lemah.

Standar Akuntansi Pemerintahan (SAP) merupakan standar yang harus diikuti dalam laporan keuangan instansi pemerintah pusat dan pemerintah daerah. Pengguna laporan keuangan akan menggunakan SAP untuk memahami informasi yang disajikan dalam laporan keuangan. Laporan pertanggungjawaban keuangan daerah (LPJ keuangan daerah) dan laporan pertanggungjawaban kinerja kepala daerah (LPJ kinerja) berpengaruh positif dan signifikan terhadap atas akuntabilitas publik pemerintah daerah dan penerapan IPSAS berpengaruh positif terhadap akuntabilitas publik pemerintah (Anondo, 2004). 
Dengan mengacu pada Standar Akuntansi Pemerintahan maka diharapkan laporan keuangan pemerintahan akan dapat diperbandingkan, sehingga sangat berguna untuk penilaian kinerja pemerintah daerah. Setiap unit kerja menentukan target dan tujuan serta merefleksikannya ke dalam suatu performance plan yang memberikan informasi mengenai jenis layanan yang disediakan, cara menyediakan layanan, obyek pemakai layanan, kualitas layanan yang diharapkan, dan tindakan yang diperlukan dalam menyediakan layanan (Jones and Pendlebury, 2000). Pengukuran kinerja memiliki kaitan erat dengan akuntabilitas, seperti halnya akuntabilitas memiliki kaitan erat dengan NPM. Untuk memantapkan mekanisme akuntabilitas, diperlukan manajemen kinerja yang didalamnya terdapat indikator kinerja dan target kinerja, pelaporan kinerja, dan mekanisme reward and punishment (Ormond and Loffler, 2002 dalam Mardiasmo,2006).

Terdapat beberapa penelitian yang berkaitan dengan kinerja, Meyer et al. (1989) menguji hubungan antara kinerja manajer tingkat atas dengan komitmen affective dan komitmen continuance pada perusahaan jasa makanan. Hasil penelitiannya menyatakan bahwa komitmen affective berkorelasi secara positif dengan kinerja, sedangkan komitmen continuance berkorelasi secara negatif dengan kinerja. Somers dan Birnbaum (1998) mengemukakan bahwa komitmen organisasional (affective dan continuance) tidak berpengaruh terhadap kinerja.

Pemerintah sebagai pelaku utama pelaksanaan good governance ini dituntut untuk memberikan pertanggungjawaban yang lebih transparan dan lebih akurat. Laporan keuangan pemerintah harus menyediakan informasi yang dapat dipakai oleh pengguna laporan keuangan untuk menilai akuntabilitas pemerintahan dalam membuat keputusan ekonomi, sosial dan politik (Sadjiarto, 2000). Dengan terciptanya pemerintahan yang bersih (good governance) meningkatkan kesadaran pemerintah daerah dalam mempertanggungjawabkan pengelolaan keuangan daerah dengan didukung oleh komitmen organisasi yang tinggi mulai dari penganggaran sampai penyusunan laporan keuangan yang sesuai dengan SAP sebagai suatu bentuk terlaksananya akuntabilitas keuangan pemerintah daerah atas aktivitas pengelolaan sumber daya publik.

Berdasarkan uraian diatas maka hipotesis penelitian (a) good governance diterapkan dengan komitmen organisasi yang tinggi maka akan berpengaruh terhadap akuntabilitas keuangan, (b) Standar Akuntansi Pemerintahan diterapkan dengan komitmen organisasi yang tinggi maka akan berpengaruh terhadap akuntabilitas keuangan, (c) penerapan good governance dan Standar Akuntansi Pemerintahan dengan komitmen organisasi yang tinggi akan berpengaruh terhadap akuntabilitas keuangan.

\section{Metode}

Penelitian ini menggunakan metode survey yang terdiri dari descriptive survey dan explanatory survey dengan investigation type yang bersifat kausalitas, yaitu yang menunjukan arah hubungan antar variabel berdasarkan konstruksi model penelitian. Pendekatan penelitian yang dilakukan dengan metode deskriptif dan verifikatif.

Unit analisis dalam penelitian ini adalah organisasi yaitu kepala SKPD dilingkungan Pemerintah Kota Bandung. Pengamatan bersifat cross section dimana informasi atau dapat yang diperoleh adalah hasil pengumpulan data yang dilakukan pada satu waktu tertentu. Sumber data yang digunakan data primer. Alat analisis yang digunakan untuk pengujian data dalam penelitian ini membutuhkan alat analisis yang mampu menjelaskan secara parsial dan simultan pengaruh dari masing-masing variabel tersebut, yaitu Mutiple Regression (regresi berganda). 


\section{Pengaruh good \\ governance}

28

\section{Operasionalisasi Variabel}

\begin{tabular}{|c|c|c|c|c|}
\hline \multirow[b]{2}{*}{$\begin{array}{l}\text { Variabel } \\
\text { Penerapan good } \\
\text { governance } \\
\text { (X1) }\end{array}$} & Konsep Variabel & Dimensi & Indikator & Skala \\
\hline & $\begin{array}{l}\text { Good governance } \\
\text { adalah, penyeleng- } \\
\text { garaan pemerintahan } \\
\text { yang solid dan } \\
\text { bertanggung jawab } \\
\text { serta efisien dan } \\
\text { efektif dengan } \\
\text { menjaga } \\
\text { kesinergiaan } \\
\text { interaksi yang } \\
\text { konstruktif diantara } \\
\text { domain- domain } \\
\text { (state, private sector } \\
\text { and society) }\end{array}$ & $\begin{array}{l}\text { 1. Transparansi } \\
\text { (Transparency) }\end{array}$ & $\begin{array}{l}\text { - Keterbukaan keuangan } \\
\text { - Keterbukaan operasional } \\
\text { - Keterbukaan pengambilan } \\
\text { keputusan } \\
\text { - Pengambilan keputusan yang } \\
\text { demokratis } \\
\text { - Kebebasan pers } \\
\text { - Kebebasan berpendapat } \\
\text { - Keterlibatan mayarakat. } \\
\text { - Pemberian informasi keuangan } \\
\text { kepada masyarakat dan } \\
\text { pemakai lainnya } \\
\text { - Menilai pertanggung jawaban. } \\
\text { - Pelaporan }\end{array}$ & Ordinal \\
\hline
\end{tabular}

(Osborne and

Geabler, 1992, OECD

and World Bank,

2000, LAN dan BPKP, 2000; 6)

Penerapan

Pernyataan

Standar

Akuntansi

Pemerintahan

(X2)

mengatur penyajian

laporan keuangan

untuk tujuan umum

(general purpose

financial statements)

dalam rangka

meningkatkan

keterbandingan

laporan keuangan

baik terhadap

anggaran, antar

periode, maupun

antar entitas.

\section{- Andal}

- Dapat

dibandingkan

- Dapat dipahami

Penerapan

Standar

Akuntansi

Pemerintahan

(X2)

- Dapat dibandingkan dengan

Ordinal

Ord

Pernyataan Standar

Pemerintahan adalah mengatur penyajian

laporan keuangan

untuk tujuan umum

(general purpose

financial statements)

dalam rangka

meningkatkan

keterbandingan

laporan keuangan

baik terhadap

anggaran, antar

periode, maupun

antar entitas.
Tabel 1

Operasionalisasi

Variabel Penelitian

\section{- Relevan}

- Andal

- Dapat

dibandingkan

- Dapat dipahami

PSAP kerangka

Konseptual (2010;

10-12)
- Memiliki manfaat umpan balik (feedback value)

- Memiliki manfaat prediktif (predictive value)

- Tepat waktu

- Lengkap.

- Penyajian Jujur

- Dapat Diverifikasi (verifiability)

- Netralitas

- Dapat dibandingkan dengan laporan keuangan periode sebelumnya laporan keuangan entitas pelaporan lain pada umumnya.

- Informasi yang disajikan dalam laporan keuangan dapat

- Memiliki manfaat umpan balik (feedback value)

- Memiliki manfaat prediktif (predictive value)

- Tepat waktu

- Lengkap.

- Penyajian Jujur

- Dapat Diverifikasi (verifiability)

- Netralitas

- Dapat dibandingkan dengan laporan keuangan periode sebelumnya

- Dapat dibandingkan dengan laporan keuangan entitas pelaporan lain pada umumnya.

- Informasi yang disajikan dalam laporan keuangan dapat dipahami oleh pengguna

- Informasi dinyatakan dalam bentuk serta istilah yang disesuaikan dengan batas pemahaman para pengguna.

ity)




\begin{tabular}{|c|c|c|c|c|}
\hline Variabel & Konsep Variabel & Dimensi & Indikator & Skala \\
\hline $\begin{array}{c}\text { Komitmen } \\
\text { Organisasi (M) }\end{array}$ & $\begin{array}{l}\text { Komitmen Organisasi } \\
\text { (Organization } \\
\text { Commitment) adalah } \\
\text { kemampuan dan } \\
\text { kemauan untuk } \\
\text { menyelaraskan } \\
\text { perilaku pribadi } \\
\text { dengan kebutuhan, } \\
\text { prioritas dan sasaran } \\
\text { organisasi. }\end{array}$ & $\begin{array}{l}\text { 1.Affective } \\
\text { Comitment } \\
\text { 2. Continuence } \\
\text { Comitment } \\
\text { 3.Normatif } \\
\text { Comitment } \\
\text { Natalie J Allen dan } \\
\text { John P Meyer } \\
\text { dalam Dunham, dkk } \\
\text { (1994) }\end{array}$ & $\begin{array}{l}\text { - Sense of belonging } \\
\text { - Emotional attached } \\
\text { - Personal meaning. } \\
\text { - Profesionalisme } \\
\text { - Pengalaman } \\
\text { - Benefit } \\
\text { - Keyakinan untuk loyal } \\
\text { - Keyakinan akan etika }\end{array}$ & Ordinal \\
\hline $\begin{array}{l}\text { Akuntabilitas } \\
\text { Keuangan } \\
\text { (Y) }\end{array}$ & $\begin{array}{l}\text { Akuntabilitas } \\
\text { keuangan merupakan } \\
\text { pertanggungjawaban } \\
\text { lembaga-lembaga } \\
\text { publik untuk } \\
\text { menggunakan dana } \\
\text { publik (public money) } \\
\text { secara ekonomis, } \\
\text { efisien dan efektif, } \\
\text { tidak ada } \\
\text { pemborosan dan } \\
\text { kebocoran dana, } \\
\text { serta mengharuskan } \\
\text { lembaga-lembaga } \\
\text { publik untuk } \\
\text { membuat laporan } \\
\text { keuangan untuk } \\
\text { menggambarkan } \\
\text { kinerja keuangan } \\
\text { organisasi kepada } \\
\text { pihak luar. } \\
\text { (Syahrudin Rasul, } \\
\text { 2003) }\end{array}$ & $\begin{array}{l}\text { 2. Pelaksanaan dan } \\
\text { pembiayaan } \\
\text { kegiatan. } \\
\text { 3. Melakukan atas } \\
\text { evaluasi kinerja keuangan. } \\
\text { kinerjan } \\
\text { 4. Pelaksanaan } \\
\text { pelaporan } \\
\text { keuangan. }\end{array}$ & $\begin{array}{l}\text { - Pengajuan anggaran sesuai } \\
\text { dengan prinsip-prinsip } \\
\text { penganggaran dan peraturan- } \\
\text { peraturan yang berlaku. } \\
\text { - Pendekatan penganggaran } \\
\text { terpadu dilakukan dengan } \\
\text { mengintegrasikan seluruh } \\
\text { proses perencanaan dan } \\
\text { penganggaran } \\
\text { - Pengajuan anggaran telah } \\
\text { disertai dengan kelengkapan } \\
\text { dokumen dan bukti pendukung } \\
\text { anggaran. } \\
\text { - Pelaksanaan belanja daerah } \\
\text { didasarkan pada prinsip hemat, } \\
\text { tidak mewah, efektif, efisien. } \\
\text { - } \text { Adanya sumber pembiayaan } \\
\text { yang jelas demi kelancaran } \\
\text { kegiatan. } \\
\text { - Kewajaran penghitungan } \\
\text { capaian kinerja keuangan. } \\
\text { - Evaluasi pencapaian kinerja } \\
\text { yang dilakukan menggunakan } \\
\text { standar-standar yang telah } \\
\text { ditetapkan } \\
\text { - Penyelenggaraan akuntansi. } \\
\text { - Laporan keuangan } \\
\text { disampaikan kepada daerah } \\
\text { melalui PPkD selambat- } \\
\text { lambatnya } 2 \text { (dua) bulan } \\
\text { setelah tahun anggaran } \\
\text { berakhir } \\
\text { - Laporan keuangan disusun } \\
\text { perdasrkan standar akuntansi } \\
\text { - }\end{array}$ & Ordinal \\
\hline
\end{tabular}

Populasi penelitian ini adalah Instansi Pemerintah Kota Bandung. Populasi sasaran dalam penelitian ini adalah Satuan Kerja Perangkat Daerah (SKPD) yang terdapat pada Pemerintah Kota Bandung. Untuk mengetahui jumlah SKPD di Pemkot Bandung, penulis mendapatkan informasi tersebut dari web site Resmi Pemerintah Kota Bandung dimana pada pemerintah kota Bandung terdapat 31 SKPD yang terdiri dari 14 lembaga teknis daerah dan 17 dinas. Pengambilan sampel dilakukan dengan cara purposive sampling dimana penulis menetapkan kriteria-kriteria tertentu yang menjadi pertimbangan dalam penentuan sampel ( $\mathrm{Coo}^{-}$ per dan Schindler, 2001).

Dinas merupakan SKPD yang secara langsung memberikan pelayanan publik melalui program dan kegiatannya secara teknis. Dinas daerah merupakan unsur pelaksana otonomi daerah (www.wikipedia otonomi daerah). Dengan menggunakan kriteria diatas yang dapat dijadikan sampel penelitian sebanyak 17 Kepala Dinas di Pemerintah Kota Bandung. 


\section{Pengaruh good governance}

30

Data Primer diperoleh dari penyebaran kuesioner dimana pertanyaan atau pernyataan dalam kuesioner untuk masing-masing variabel dalam penelitian ini diukur dengan menggunakan skala Likert dimana jawaban diberi skor dengan menggunakan 5 (lima) point Skala Likert (Sekaran, 2000).

Analisis data dalam penelitian ini membutuhkan alat analisis yang mampu menjelaskan secara parsial dan simultan pengaruh dari masing-masing variabel tersebut, yaitu, dengan menggunakan Mutiple Regression (regresi berganda), analisis korelasi berganda dan analisis determinasi. Peneliti melakukan uji asumsi klasik dan uji validitas dilakukan dengan uji homogenitas data, yaitu dengan melakukan uji korelasi antara skor item-item pertanyaan dengan skor total. Uji validitas yang digunakan adalah Korelasi Product Moment, dengan syarat minimum suatu item dianggap valid adalah nilai $r=0,30$ (Sugiyono, 2001:116).. Uji reliabilitas instrumen penelitian dilaksanakan dengan melihat konsistensi koefisien Cronbach Alpha untuk semua variabel. Menurut Nunnaly (1978) dalam Ghozali (2002), Sekaran, (2000,204). instrumen penelitian dikatakan handal (reliable), jika nilai Cronbach Alpha lebih dari 0,6. Hal ini berarti instrumen penelitian dinyatakan reliabel.

\section{Hasil}

Hasil pengujian validitas kuesioner penelitian menggunakan Korelasi Product Moment, dimana dari 46 item pertanyaan yang terdiri 18 item untuk variabel $\mathrm{X} 1,12$ item untuk variabel X2 dan 16 item untuk variabel Y dan 12 item untuk variabel $\mathrm{M}$ diperoleh $\mathrm{r}$-hitung diatas 0,3 sehingga semua item dalam kuesioner penelitiaan valid. Selanjutnya dilakukan uji reliabilitas dengan menggunakan koefisien Cronbach Alpha untuk semua variabel dan diperoleh hasil nilai Cronbach Alpha diatas 0,6. Untuk variabel X1, X2, Y dan M masing-masing nilai Cronbach Alpha sebesar 0,901, 0,861, 0,894 dan 0,938 sehingga semua variabel reliabel.

Dari hasil jawaban kuesioner responden atas item pertanyaan dari masingmasing variabel penelitian adalah sebagai berikut:

\begin{tabular}{lcc}
\hline \multicolumn{1}{c}{ Variabel Penelitian } & Skor & Kriteria \\
\hline Penerapan Good Governance (X1) & 1333 & Baik \\
Penerapan Standar Akuntansi Pemerintahan (X2) & 830 & Baik \\
Akuntabilitas Keuangan (Y) & 1175 & Baik \\
Komitmen Organisasi (M) & 846 & Tinggi \\
\hline
\end{tabular}

Setelah dilakukan analisis dengan menggunakan regresi berganda dengan bantuan software SPSS versi 18,0 maka diperoleh persamaan sebagai berikut:

$$
\mathrm{Y}=-1.992+0.51 \mathrm{X} 1+0.229 \mathrm{X} 2+0.003 \mathrm{X} 1 \mathrm{M}+0.12 \mathrm{X} 2 \mathrm{M}
$$

Dari hasil tersebut dapat dipersepsikan bahwa jika penerapan good governance yang diikuti dengan komitmen organisasi naik 1 satuan dan standar akuntansi pemerintahan dianggap tetap maka akuntabitas keuangan akan naik sebesar 0.003 satuan. Kemudian apabila penerapan standar akuntansi pemerintahan yang diikuti dengan komitmen organisasi naik 1 satuan dan good governance tetap maka akuntabilitas keuangan akan naik 0.12 satuan.

Model Summary

a. Predictor:

(Contant), X2M,

Standar Akuntansi

Pemerintahan,

Good Governance, $\mathrm{X} 1 \mathrm{M}$

b. Dependent Variable: Akuntabilitas Keuangan

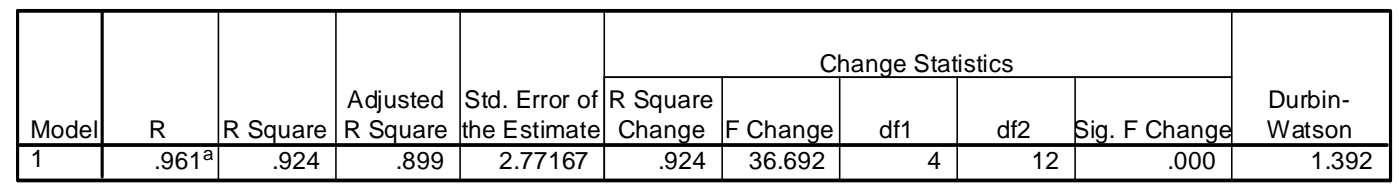




\begin{tabular}{|c|c|c|c|c|c|c|c|c|c|c|c|}
\hline \multirow[b]{2}{*}{ Mod } & & \multicolumn{2}{|c|}{$\begin{array}{c}\text { Unstandardized } \\
\text { Coefficients }\end{array}$} & \multirow{2}{*}{\begin{tabular}{|c|}
$\begin{array}{c}\text { Standardized } \\
\text { Coefficients }\end{array}$ \\
Beta \\
\end{tabular}} & \multirow[b]{2}{*}{$\mathrm{t}$} & \multirow[b]{2}{*}{ Sig. } & \multicolumn{3}{|c|}{ Correlations } & \multicolumn{2}{|c|}{ Collinearity Statistics } \\
\hline & & $\mathrm{B}$ & Std. Error & & & & Zero-order & Partial & Part & Tolerance & VIF \\
\hline \multirow[t]{5}{*}{1} & (Constant) & -1.992 & 4.873 & & -.409 & .690 & & & & & \\
\hline & Good Governance & .510 & .100 & .537 & 5.084 & .000 & .850 & .826 & .403 & .564 & 1.774 \\
\hline & $\begin{array}{l}\text { Standar Akuntans } \\
\text { Pemerintahan }\end{array}$ & .229 & .093 & .219 & 2.458 & .030 & .574 & .579 & .195 & .796 & 1.256 \\
\hline & $\mathrm{X} 1 \mathrm{M}$ & .003 & .001 & .277 & 2.519 & .027 & .790 & .588 & 200 & .520 & 1.923 \\
\hline & $\mathrm{X} 2 \mathrm{M}$ & .012 & .004 & .268 & 3.263 & .007 & .460 & 686 & .259 & .934 & 1.070 \\
\hline
\end{tabular}

\begin{tabular}{|c|c|c|c|c|c|c|}
\hline & & $\begin{array}{c}\text { Akuntabilitas } \\
\text { Keuangan }\end{array}$ & $\begin{array}{c}\text { Good } \\
\text { Governance }\end{array}$ & \begin{tabular}{|c|} 
Standar \\
Akuntansi \\
Pemerintahan \\
\end{tabular} & $\mathrm{X} 1 \mathrm{M}$ & $\mathrm{X} 2 \mathrm{M}$ \\
\hline \multicolumn{2}{|c|}{ Pearson Correlatio Akuntabilitas Keuang } & 1.000 & .850 & .574 & .790 & .460 \\
\hline \multicolumn{2}{|c|}{ Good Governance } & .850 & 1.000 & 382 & .651 & 181 \\
\hline \multirow{2}{*}{\multicolumn{2}{|c|}{$\begin{array}{l}\text { Standar Akuntansi } \\
\text { Pemerintahan } \\
\text { X1M }\end{array}$}} & .574 & .382 & 1.000 & .432 & .113 \\
\hline & & .790 & .651 & .432 & 1.000 & .255 \\
\hline & $\mathrm{X} 2 \mathrm{M}$ & .460 & .181 & .113 & .255 & 1.000 \\
\hline \multirow[t]{5}{*}{ Sig. (1-tailed) } & Akuntabilitas Keuang & & .000 & .008 & .000 & .031 \\
\hline & Good Governance & .000 & & .065 & .002 & .244 \\
\hline & $\begin{array}{l}\text { Standar Akuntansi } \\
\text { Pemerintahan }\end{array}$ & .008 & .065 & & .042 & .333 \\
\hline & $\mathrm{X} 1 \mathrm{M}$ & .000 & .002 & .042 & & .161 \\
\hline & $\mathrm{X} 2 \mathrm{M}$ & .031 & .244 & .333 & .161 & \\
\hline \multirow[t]{5}{*}{$\mathrm{N}$} & Akuntabilitas Keuang & 17 & 17 & 17 & 17 & 17 \\
\hline & Good Governance & 17 & 17 & 17 & 17 & 17 \\
\hline & $\begin{array}{l}\text { Standar Akuntansi } \\
\text { Pemerintahan }\end{array}$ & 17 & 17 & 17 & 17 & 17 \\
\hline & $\mathrm{X} 1 \mathrm{M}$ & 17 & 17 & 17 & 17 & 17 \\
\hline & X2M & 17 & 17 & 17 & 17 & 17 \\
\hline
\end{tabular}

Coefficients

a. Dependent Variable: Akuntabilitas

Keuangan

Uji asumsi klasik meliputi uji normalitas, autokorelasi, multikolinieritas, dan heteroskedastisitas. Dari pengujian secara statistik diperoleh data residual pada penelitian ini terdistribusi secara normal. Model regresi juga menunjukkan bahwa tidak terjadi autokorelasi, multikolinearitas antar variabel bebas dalam model regresi dimana nilai VIF $<10$. Selain itu, secara statistik model regresi pada penelitian ini tidak mengandung adanya heteroskedastisitas.

Untuk melihat pengaruh dari masing-masing variabel independen terhadap variabel dependen bahwa secara parsial penerapan Good Governance dengan komitmen organisasi yang tinggi berpengaruh pada akuntabilitas keuangan sebesar $67,5 \%$, sedangkan penerapan standar akuntansi pemerintahan dengan komitmen organisasi yang tinggi berpengaruh terhadap akuntabilitas keuangan sebesar $24,9 \%$. Secara simultan penerapan good governance dan standar akuntansi pemerintahan dengan komitmen organisasi tinggi dalam mempengaruhi akuntabilitas keuangan diperoleh hasil sebesar $92.4 \%$ sedangkan $7.6 \%$ adalah pengaruh dari faktor lain yang tidak diteliti oleh penulis seperti partisipasi penyusunan anggaran dan anggaran berbasis kinerja dan lain-lain. Dengan memasukan variable pemoderasi memperkuat pengaruh X1, X2 ke Y sebesar 12,9\% dimana tanpa memasukan komitmen organisasi (M) besar pengaruh $\mathrm{X} 1$, X2 terhadap $\mathrm{Y}$ hanya sebesar $79,5 \%$.

Selanjutnya hubungan penerapan Good Governance dan standar akuntansi pemerintahan dengan komitmen organisasi yang tinggi mempunyai hubungan yang erat (kuat) dengan akuntabilitas keuangan dimana diperoleh koefisien korelasi sebesar $96,1 \%$. Dengan memasukan variabel pemoderasi terbukti memperkuat hubungan X1, X2 ke Y dari 89,2 \% menjadi 96,1\%. Hasil penelitian ini sesuai dengan penelitian Black (2001), Durnev dan Kim (2002), Andono (2004) dan Darma (2004) dimana good governance, SAP/IPSAS dan komitmen organisasi mempunyai pengaruh terhadap akuntabilitas publik (keuangan). 


\section{Pengaruh good governance}

\section{Pembahasan}

Sesuai dengan misi Pemerintah Kota Bandung pada butir ke 5 (lima) yaitu meningkatkan kinerja pemerintah kota secara professional, efektif, efisien akuntabel dan transparan, yang mencakup pemberdayaan aparatur pemerintah dan masyarakat maka Pemerintah Kota Bandung tetap memegang teguh agar terwujudnya pemerintahan yang bersih dan berwibawa (good governance). Ini terlihat dari dilaksanakan tiga pilar good governance yaitu transparansi informasi keuangan dan non keuangan, mengikutsertakan partisipasi masyarakat melalui peran DPRD sebagai legislatif, para akademisi dalam membantu membuat kajian, sistem dan prosuder keuangan daerah, aset daerah dan lainya. Secara periodik mempertanggungjawabkan pengelolaan keuangan daerah baik ditingkat Dinas sampai pemkot bandung dalam bentuk LKPD yang selanjutnya akan diaudit oleh inspektorat wilayah, BPKP dan BPK wilayah Bandung. Pemkot Bandung sebagai pelaku utama pelaksanaan good governance telah memberikan pertanggungjawaban yang transparan dan akurat dalam menyediakan informasi untuk menilai kinerja dan akuntabilitas pemerintahan termasuk akuntabilitas keuangan (Osborne dan Geabler, 1992; Cadbury, 1992; Black, 2001; Sadjiarto, 2000; Sunarto, 2003)

Sehubungan dengan upaya peningkatan good governance, Komisi Pemberantasan Korupsi (KPK) segera menerjunkan timnya ke Kota Bandung untuk mengasistensi pemerintah kota tersebut mereformasi birokrasinya. Kota Bandung perlu melakukan upaya-upaya reformasi birokrasi terutama yang terkait dengan pelayanan publik. Untuk mencegah terjadinya korupsi, markup, pungli, dan suap, tidak cukup hanya dengan melakukan reformasi birokasi. Perlu juga dilakukan langkah-langkah untuk menyejahterakan pejabat dan rakyatnya. Kalau rakyatnya sudah sejahtera, pejabat dan birokratnya sudah sejahtera, keterlaluan bila masih ada pejabat yang korupsi. Komitmen organisasi yang tinggi dari walikota, sekda, kepala dinas dan semua aparat terkait untuk tetap menjadikan kota Bandung menjadi kota dengan pemerintahan yang bersih dan berwibawa (good governance), perlu adanya tauladan mulai dari walikota dan sektaris daerah kepada kepala dinas selanjutnya kepala dinas pegawai yang berada dilingkungan dinas yang dipimpinya terkait dengan pelaksanaan tugas di pemkot Bandung karena akan berdampak pada kedisiplinan, kesadaran, dan etika serta tanggung jawab yang tinggi atas tugas-tugas yang diembannya. Ini dapat berdampak pada kesadaran untuk melaksanakan akuntabilitas publik termasuk keuangan secara sukarela. Kurangnya tataran pembinaan atas kegiatan pengelolaan keuangan yang dilakukan oleh kepala daerah kepada para kepala dinas dimana kesadaran dalam mengikuti kegiatan pelatihan, rapat, seminar dan workshop yang seharusnya diikuti oleh para kepala dinas tetapi hanya diwakili oleh staf karena pada saat acara tersebut tidak hadir walikota atau sekwida. Ini menunjukkan kurangnya komitmen terhadap organisasi yang dipimpinya.

Penyusunan laporan pertanggungjawaban atas pelaksanaan keuangan daerah dalam bentuk laporan keuangan pemerintah daerah (LKPD), Pemerintah Kota Bandung menggunakan Standar Akuntansi Pemerintahan (SAP) dan Kebijakan Akuntansi sebagai pedoman penyusunan laporan keuangan. Kualitas Laporan Keuangan Pemerintah Daerah (LKPD) kota Bandung tahun 2009 justru jauh lebih buruk ketimbang LKPD tahun 2008. Untuk kota Bandung, hasil pemeriksaan BPK memberikan opini Disclaimer atau Menolak Menyatakan Opini untuk LKPD tahun 2009. Pada tahun 2009 lalu, kota Bandung mendapat penilaian Wajar Dengan Pengecualian (WDP) untuk LKPD tahun 2008. Pemahaman dan implementasi SAP sangat mempengaruhi laporan keuangan, ketidak sesuai penyusunan laporan keuangan pemkot bandung dengan ketentuan dalam Pernyataan Standar Akuntansi Pemerintahan(PSAP) menyebabkan opini atas LKPD tahun 2009 dis $^{-}$ claimer. Hal ini menyebabkan menurunnya kinerja pemkot Bandung karena pengukuran kinerja memiliki kaitan erat dengan akuntabilitas, dengan mengacu pada Standar Akuntansi Pemerintahan maka diharapkan laporan keuangan akan dapat diperbandingkan, sehingga sangat berguna untuk penilaian kinerja pemkot Bandung. Laporan keuangan tersebut merupakan komponen penting untuk mencip- 
takan akuntabilitas sektor publik dan merupakan salah satu alat ukur kinerja keuangan pemerintah daerah. Akuntabilitas keuangan sangat terkait dengan pelaporan keuangan (Ormond and Loffler, 2002; Daru Andoro, 2004; Mardiasmo,2006)

Beberapa hal yang menyebabkan kota Bandung mendapat penilaian Disclaimer, lanjut, diantaranya penyajian dan/atau pengungkapan penyertaan modal pemerintah kepada perusahaan daerah diatas $20 \%$ tidak disajikan dengan metode ekuitas sebagaimana dinyatakan dalam Standar Akuntansi Pemerintahan. Selain itu, penyajian aset tetap tidak didukung dengan rincian daftar aset maupun dokumen berupa daftar inventarisasi dan penilaian aset tersebut. Jikapun daftar inventarisasi tersebut dimiliki, data tersebut sudah tidak mutakhir dan tidak valid. Ini disebabkan mutasi barang antar SKPD tidak diikuti dengan mutasi pencatatannya. Masalah manajemen aset yang dinilai buruk dan berpotensi merugikan negara sebesar 800 milyar rupiah. Baik Wali Kota Bandung Dada Rosada maupun Sekretaris Daerah Kota Bandung Edi Siswadi saat itu berjanji untuk segera membenahi sistem pengelolaan aset daerah.

Kurangnya tenaga akuntansi dibagian keuangan dan penatausahaan (PPKSKPD) menyulitkan dalam memahami standar akuntansi pemerintahan. Komitmen yang tinggi dari pemkot Bandung untuk melakukan pembenahan dalam sistem pengelolaan aset daerah harus diikuti di semua lapisan manajemen pemerintahan mulai dari walikota, sekda, kepala dinas dan kepala SKPD lainnya serta DPRD kota Bandung agar semuanya dapat berjalan dengan baik sehingga opini atas LKPD kota Bandung dimasa yang akan datang menjadi wajar dengan pengecualian (WDP) bahkan wajar tanpa pengecualian (WTP).

Akuntabilitas keuangan, mulai dari perumusan rencana keuangan (proses penganggaran), pelaksanaan dan pembiayaan kegiatan, evaluasi atas kinerja keuangan, dan pelaksanaan pelaporannya. Setiap informasi yang dihasilkan oleh setiap SKPD akan di laporkan kepada Dinas Pengelolaan Keuangan dan Aset daerah (DPKAD) Kota Bandung yang selanjutnya akan dikonsolidasikan menjadi LKPD dan akan disampaikan kepada DPRD setiap tahunya untuk mendapatkan pengesahan melalui Perda APBD. Hal ini dilakukan sehubungan dengan kewajiban pemda Kota Bandung untuk mempertanggungjawabkan atas penggunaan APBD dalam penyelenggaraan pembangunan dan untuk dapat mengetahui capain kinerja dari setiap program dan kegiatan.

Dilakukan evaluasi kinerja keuangan dengan memperhatikan prinsip ekonomis, efektif dan efisien dari setiap program dan kegiatan yang dilakukan atas penggunaan anggarannya oleh setiap dinas di kota Bandung. Evaluasi pencapaian kinerja yang dilakukan menggunakan standar-standar yang telah ditetapkan terlebih dahulu seperti Standar Pelayanan Minimal (SPM) dan Analisis Standar Belanja (ASB) dan standar satuan harga untuk mengetahui capaian dari program dan kegiatan yang dilakukan.

Pemerintah Kota Bandung melakukan transparansi dan akuntabitas keuangan atas pengelolaan keuangan daerah agar publik dapat mengetahu kinerja yang telah dicapai dan wujud tanggungjawab atas penggunaan dana publik. Laporan keuangan dinas (SKPD) dan pemkot Bandung (SKPKD) disajikan sesuai dengan Standar Akuntansi Pemerintahan yang akan diaudit oleh inspektorat wilayah kota Bandung dan juga diaudit oleh BPKP apabila ada permasalah dalam laporan keuangan bukan hanya mengenai proyek tapi keuangan lainnya ini atas permintaan kejaksaan. Selanjutnya LKPD kota Bandung setiap tahunnya diaudit oleh BPK wilayah bandung untuk melihat kewajaran laporan keuangan dan BPK akan memberikan opini atas LKPD, dan untuk tahun LKPD tahun 2009 kota Bandung mendapatkan opini Disclaimer.

Komitmen organisasi yang tinggi berpengaruh terhadap kinerja pemerintah daerah. Komitmen organisasi dapat merupakan alat bantu psikologis dalam menjalankan organisasinya untuk pencapaian sasaran yang diharapkan. Semakin baik komitmen organisasi akan mendorong keberhasilan akuntabilitas publik termasuk akuntabilitas keuangan. Pada pemerintah daerah, aparat yang merasa sasaran anggarannya jelas, akan lebih bertanggungjawab jika didukung dengan komitmen 


\section{Pengaruh good governance}

aparat yang tinggi terhadap organisasi (instansi) pemerintah daerah. Aparat akan lebih mementingkan kepentingan organisasi daripada kepentingan pribadi. Hal ini akan mendorong aparat untuk menyusun anggaran sesuai dengan sasaran yang ingin dicapai oleh organisasi sehingga berdampak pada kinerja aparat dalam rangka mewujudkan good governance (Nouri dan Parker, 1996; Keller, 1997 ; McClurg, 1999; Chong dan Chong, 2002; Wentzel, 2002; Darma, 2004; Abdullah, 2004; Bambang,2006).

Pemerintah Kota Bandung terus berkomitmen untuk meningkatkan kualitas pelayanan publik di berbagai program, salah satunya seperti pada program "bawaku sehat" dimana pemkot Bandung melalui Dinas Kesehatan menyediakan layana kesehatan gratis bagi warga miskin di kota Bandung sebanyak +350.000 warga yang sudah terdata pada kelurahan dan kecamatan masing-masing dan mengupayakan tersedianya data base online disemua rumah sakit yang menerima layanan ini. Program ini diluncurkan untuk menampung masyarakat miskin yang tidak tercover dalam Jamkesmas, Jamkesda dan Gakin.

Semua langkah yang dilakukan sesuai dengan strategi Pemerintah Kota Bandung dalam rangka meningkatkan kinerja pemerintah kota secara efektif, efesien, transparan dan akuntabel dengan kebijakan mengupayakan terjadinya peningkatan pelayanan pemerintah kepada masyarakat dan meningkatkan partisipasi masyarakat dalam perencanaan, pelaksanaan serta pengendalian pengawasan pembangunan kota. Komitmen yang tinggi dan integritas dari pemerintah daerah dan kepala dinas sangat diperlukan untuk melaksanakan langkah dan strategi yang telah disusun oleh Pemerintah Kota Bandung agar peningkatan kinerja pemerintah kota secara efektif, efesien, transparan dan akuntabel dapat tercapai.

\section{Simpulan}

Pemerintah Kota Bandung tetap memegang teguh agar terwujudnya pemerintahan yang bersih dan berwibawa (good governance). Ini terlihat dari dilaksanakan tiga pilar good governance yaitu transparansi informasi keuangan dan non keuangan, mengikutsertakan partisipasi masyarakat melalui peran DPRD sebagai legislatif, para akademisi dalam membantu membuat kajian, sistem dan prosuder keuangan daerah, aset daerah dan lainya.

Pemerintah Kota Bandung melakukan transparansi dan akuntabitas keuangan atas pengelolaan keuangan daerah agar publik dapat mengetahui kinerja yang telah dicapai dan wujud tanggungjawab atas penggunaan dana publik. Laporan keuangan dinas (SKPD) dan pemkot Bandung (SKPKD) disajikan sesuai dengan Standar Akuntansi Pemerintahan yang akan diaudit oleh inspektorat wilayah kota Bandung dan juga diaudit oleh BPKP apabila ada permasalah dalam laporan keuangan bukan hanya mengenai proyek tapi keuangan lainnya ini atas permintaan kejaksaan. Selanjutnya LKPD kota Bandung setiap tahunnya diaudit oleh BPK wilayah bandung untuk melihat kewajaran laporan keuangan dan BPK akan memberikan opini atas LKPD, dan untuk tahun LKPD tahun 2009 kota Bandung mendapatkan opini Disclaimer yang mana hasil ini lebih buruk dari opi LKPD tahun 2008, oleh sebab itu Wali Kota maupun Sekretaris Daerah Kota Bandung saat itu berjanji untuk segera membenahi sistem pengelolaan aset daerah. Pentingnya pemahaman atas SAP merupakan keharusan dalam penyusunan laporan keuangan, hal ini terkait dengan opini atas LKPD.

Penerapan good governance dan standar akuntansi pemerintahan dengan komitmen organisasi yang tinggi mempunyai pengaruh terhadap akuntabilitas keuangan Pemerintah Kota Bandung sebesar 92.4\% yang artinya komitmen organisasi yang merupakan variabel kontinjensi sangat mempengaruhi akuntabilitas keuangan yang mana pemahaman dan penggunaan SAP mutlak dilakukan agar laporan keuangan berkualitas dan dapat menilai kinerja aparatur pemerintah yang bersih dan berwibawa. 
Arja, Sadjiarto. 2000. "Akuntabilitas dan Pengukuran Kinerja Pemerintahan". Jurnal Akuntansi \& Keuangan. Vol. 2, No. 2, Nopember 2000: 138 - 150

Abdullah, H. 2004. "Pengaruh Kejelasan Sasaran Anggaran, Pengendalian Akuntansi dan Sistem Pelaporan Terhadap Akuntabilitas Kinerja Instansi Pemerintah Pada Kabupaten dan Kota di Daerah Istimewa Yogyakarta”. Tesis. Program Pasca Sarjana UGM: Yogyakarta.

BPKP. 1998. Pengukuran Kinerja: Akuntabilitas Kinerja Instansi Pemerintah. Jakarta

Brownell, P. 1982. "A Field Study Examination of Budgetary Participation and Locus of Control”. The Accounting Review. Vol. LVII (4). October: 766-777.

Brownell, P. dan M. McInnes. 1986. "Budgetary Participation, Motivation, and Managerial Performance". The Acccounting Review. Vol. LXI(4). October: 587600 .

Charles Lenvine. 1990. Public Administration: Challenges, Choice, Consequences. Glenview Illinois: Scott Foreman/Little Brown Higher Education.

Charlos, P. dan M. C. C. Poon. 2000. "Participation and Performance in Capital Budgeting Teams". Behavioral Research In Accounting. Vol 12. 197-229.

Chong, V. K. dan K. M. Chong. 2002. "Budget Goal Commitment and Informational Effect of Budget Participation on Performance". A Structural Equation Modeling Approach. Behavioral Research In Accounting. Vol 14. 65-86.

Darlis, E. 2000. "Analisis Pengaruh Komitmen Organisasional dan Ketidakpastian Lingkungan terhadap Hubungan Antara Partisipasi Anggaran dengan Senjangan Anggaran". Tesis. Program Pasca Sarjana UGM: Yogyakarta.

Darma, E. S. 2004. "Pengaruh Kejelasan Sasaran dan Sistem Pengendalian Akuntansi Terhadap Kinerja Manajerial dengan Komitmen Organisasi sebagai Variabel Pemoderasi pada Pemerintah Daerah”. Tesis. Program Pasca Sarjana UGM: Yogyakarta.

Djamaludin Antjok. 1999. "Penyelenggaraan Good Governance di Indonesia". Makalah disampaikan pada Diskusi Panel Penyelenggaraan Good Governance di Indonesia yang diselenggarakan oleh Lembaga Administrasi Negara. Jakarta.

Fernando, J., Mulki, J.P., dan Marshall, G.W. 2005. "A Meta-Analysis of The Relationship Between Organizational Commitment and Salesperson Job Performance". Jounal of Business Research, (58): 705-714.

Fisman, Raymond, and Roberta Gatti. 2002."Decentralization and Corruption: Evidence across Countries." Journal of Public Economics 83 (3): 325-45.

Grindle, M.S., (editor). 1997. Getting Good Government: Capacity Building in the Public Sector of Developing Countries. Boston. MA: HArvard Institue for International Development.

Govermental Accounting Standard Board (1994). "Concepts Statements No. 2, Service Effort sand Accomplishment Reporting", www.rutgers.edu/Accounting/ raw/seagov/pmg/perfmeasure. September 2000.

Grindle, M.S., (editor), 1997, Getting Good Government: Capacity Building in the Public Sector of Developing Countries, Boston, MA: HArvard Institue for International Development.

Huther, Jeff and Anwar Shah, 1998. "Applying a Simple Measure of Good Governance to the Debate of Fiscal Decentralization". Policy Research Woking Paper 1894, World Bank, Wasingthon, DC.

International Federation of Accountants, 2000, Preface to International Public Sector Accounting Standards, New York.

Peraturan Pemerintah Republik Indonesia Nomor 71 Tahun 2010 Tentang Standar Akuntansi Pemerintahan. 


\section{Pengaruh good governance}

Jones, Rowan dan Maurice Pendlebury (1996). Public Sector Accounting. Edisi keempat. London: Pitman Publishing. McMahon, Tom (1996). "Access to Gov' ernment Information: A New Instrument for Public Accountability" Government Information in Canada, Volume 3, Number 1.

Kenis, I. 1979. "Effects on Budgetary Goal Characteristic on Managerial Attitudes and Performance". The Accounting Review LIV (4). 707-721.

Kluvers, R. 2001. "Program Budgeting and Accountability in Local Government". Australian Journal of Public Administration. Vol 60 (2). Juni: 35-43.

2003. Accountability for Performance in Local Government, Departement of Accounting and Financial Sector University Technology National Council of the Institue Public Administration. Autralia. 2003.

Kravcuk,Robert S dan Schack,Ronal W. Juli/August 1996. "Designing effective performance meaurement system under the Government Performance and Result Act of 1993”. Public administration Revie. Vol.56 No.4, hal.348-358

Kusmayadi, 2005. Upaya Mewujudkan Good Government Governance Melalui Pengelolaan Keuangan Daerah. Pascasarjana IPB.

Komite Standar Akuntansi Pemerintahan. 2006. Memorandum Pembahasan Penerapan Basis Akrual Dalam Akuntansi Pemerintahan Indonesia.

LAN, BPKP. 2001. Pengukuran kinerja instansi pemerintah, Modul Sosialisasi Sistem Akuntabilitas Kinerja Instansi Pemerintah (AKIP). Lembaga Administrasi Negara. Jakarta.

Lembaga Adminstrasi Negara.2003. Pedoman Penyusunan Pelaporan Akuntabilitas Kinerja Instansi Pemerintah.

Morfit, Goerge L. 1995. "Performance Measurement nad Accountability in Victorian Local Government”. The International Jounal Of Public Sector. Vol. 12, pp. 565-584.

Meyer, J.P and Allen, N.J. 1997. "Commitment in the Workplace: Theory, Research and Application". Jounal of Vacation Behavior. Vol. 14, pp 24-27.

Mayston, David, J.1985. "Non-Profit Performance Indicator in The Public Sector". Financial Accountability and Management, hal.51-74.

Mardiasmo. 2004. "Membangun Akuntabilitas Publik Keuangan Negara". Cetakan Majalah Media Akuntansi. Edisi No. 39, April, hal. 12.

Mardiasmo. 2006. "Pewujudan Transparansi dan Akuntabilitas Publik Melalui Akuntansi Sektor Publik: Suatu Sarana Good Governance". Jurnal Akuntansi Pemerintahan. Vol. 2, No. 1, Mei 2006.

McClurg, L.N. 1999. "Organizational Commitment in The Temporary Help Service Industry". Journal of Applied Management Studies. 5-26

Nouri, H. dan R. J. Parker. 1996. "The Effect of Organizational Commitment on Relation Between Budgetary Participation and Budgetary Slack”. Behavioral Research In Accounting. Vol 8. 74-90.

Osborne, David, and Gaebler. 1992. Reinveting Government: How the entrepreneurial spirit is Transforming the Public Sektor, New York: Penguinsc Book.

Parker, Wayne C. 1993. "Performance Measurement in the Public Sector". State of Utah. www.rutgers.edu/Accounting/raw/seagov/pmg/perfmeasure. September 2000.

Propper, Carol dan Wilson, Deborah, Summer 2003. "The use and Usefulness of Performance Measures in The Public sector". Oxford Review of Economic Policy. Vol.19 no.2,hal.250-267.

Rondinelli. 1983. "Government Decentralization in Comparative Perspective: Theory And Practice in Developing Countries". International Review of Administrative Sciences. No. 1

Rowan dan Maurice Pendlebury (1996). Public Sector Accounting. Edisi keempat. London: Pitman Publishing. McMahon. 
Republik Indonesia. Undang-Undang RI No. 32 Tahun 2004. tentang Pemerintah Daerah.

Peraturan Pemerintah no. 24 tahun 2005. Standar Akuntansi Pemerintahan.

Sekaran, Uma. 2000. Research Methods For Business: A Skill-Building Approach. Third Edition. John Wiley \& Sons. Inc. New York.

Somers, M.J. dan Birnbaum, Dee. 1998. "Work-Related Commitment and Job Performance: It's Also The Nature of The Performance That Counts". Journal of Organizational Behavior, (19): 621-634.

Shah,Anwar, and Mark Schacter. 2004."Combating Corruption: Look before You Leap."

Finance and Development (International Monetary Fund), 41 (4): 40-43.

Tom (1996). "Access to Government Information: A New Instrument for Public Accountability". Government Information in Canada. Volume 3, Number 1.

World Bank. 2004. Mainstreaming Anticorruption Activities in World Bank Assistance: A Review of Progress since 1997. Washington, DC: World Bank.

Wentzel, K. 2002. "The Influence of Fairness Perceptions and Goal Commitment on Managers Performance in a Budget Setting". Behavioral Research In Accounting. Vol 14. 247-271.

Whittaker James B. 1995. The Government Performance and Result Act of 1993: A Mandate for Strategic Planning and Performance Measurement. Educational Services Institute. Arlington. Virginia.

Widodo, Joko. 2001. Good Governance, Telaah dari Dimensi Akuntabilitas dan Kontrol Birokrasi Pada Era Desentralisasi dan Otonomi Daerah. Insan Cendekia. Surabaya.

Yuhertiana, I. 2007. "Principal-Agent Theory dalam Proses Perencanaan Anggaran Sektor Publik". KOMPAK: Jurnal Akuntansi, Manajemen, dan Sistem Informasi FE UTY Yogyakarta. No: 9. April. 403-422. 
